\title{
THE SWEDISH SOCIAL LANDSCAPE IN SOCIAL WORK PRACTICE WITH VULNERABLE YOUNG POPULATIONS
}

\author{
Irena Dychawy Rosner \\ Malmö University
}

\begin{abstract}
A substantial number of young people in Western countries are facing severe difficulties due to wider social, political and economic change. Using a review of the literature and a descriptive approach, this paper explores issues of youth education, training, employment and social capital on the Swedish welfare landscape, as important factors in the education of the social professions, to understand and meet the needs of young vulnerable populations. The research found growing uncertain conditions in young populations, growing socio-economic vulnerability, mental ill-health and insufficient access to the labour market. Furthermore, the results of the paper suggest shortcomings in the social services for disadvantaged young people, and current socio-political programmes seem to reinforce the existing pattern of inequality. The insights generated by this study have the ability to inform international, national and local evidence bases in this area. It may contribute to the support of reflective future practitioners who use research as an integral element of improving their holistic client-centred interventions. The article has been prepared in the frame of the project „Social Professions for Youth Education in the Context of European Solidarity“* with participation of Latvian, Lithuanian, Polish, and Swedish universities that deliver programmes of training social professionals.

KEY WORDS: health and society, social professions, youth welfare, vulnerability, health and society.
\end{abstract}

\begin{abstract}
Anotacija
Nemažai žmonių Vakarų šalyse dẻl nuolat vykstančiu socialinių, politinių ir ekonominių pokyčių patiria didelių sunkumų. Straipsnyje, taikant literatūros analizės ir aprašomajji metodus, tyrinejjami Švedijos socialinès gerovès klausimai, apimantys jaunimo švietimą, profesinį rengimą, įdarbinimą ir socialinị kapitalą. Tai svarbūs socialinès srities specialistų rengimo aspektai, padedantys suprasti ir užtikrinti pažeidžiamų jaunimo grupių poreikius. Tyrimas atskleide didèjantị jaunimo neapibrèžtumą, socioekonomini pažeidžiamumą, psichikos sveikatos problemas ir menką įsitraukimą ị darbo rinką. Atskleistas ne tik socialinių paslaugų pažeidžiamiems jaunuoliams trūkumas, bet ir pastebèta, kad vykdomos sociopolitinès programos esamą nelygybę dar labiau didina. Šio tyrimo įžvalgos gali būti naudingos tarptautiniu, nacionaliniu ir vietiniu lygmenimis. Jos gali prisidèti prie būsimų specialistų, kurie taikys tyrimus, kaip integralią jų visa apimančios, ị klientą orientuotos praktikos dalį, rengimo. Straipsnis parengtas kaip projekto „Socialinès jaunimo ugdymo profesijos Europos solidarumo kontekste“, kuriame dalyvauja Latvijos, Lietuvos, Lenkijos, Švedijos universitetai, rengiantys socialiniu profesijų specialistus, dalis.

PAGRINDINIAI ŽODŽIAI: sveikata ir visuomenè, socialinès srities profesijos, jaunimo gerovè, pažeidžiamumas.
\end{abstract}

DOI: http://dx.doi.org/10.15181/tbb.v83i2.2063

* Project: Social Professions for Supporting Youth in a European Solidarity Context; Erasmus+KA203 - Strategic Partnerships for higher education, (2019-1-PL01-KA203-065091) 
Irena Dychawy Rosner

\section{Introduction}

As immense factors determining young people's welfare and well-being occur in societies, it is important for future social professions (e.g. social workers, social pedagogues, teachers and others working in humanitarian organisations) to develop a critical understanding of the essentials relating to social vulnerability, poverty and social ill-health (Dychawy Rosner, 2017; Halleröd, 2006; Svärd, 2017). Abbott (1988) emphasised that professionals are knowledge carriers, and their work is based on scientific principles. Professionals manage a certain type of knowledge in a collegial organisational form with political legitimacy. Essentially, social professions are knowledge-based occupations which usually possess a high degree of autonomy and collegial organisation. The social professions in the Scandinavian countries have historically been strongly linked to the state and the bureaucratic order (Brante, 2013).

The expression of poverty and vulnerability in Sweden, and their spread, have long been a much-debated topic. Concepts of poverty and vulnerability are not clearly defined, either in academic settings or among the public. The scope of these concepts are perceived as very central, since minimising their consequences is one of the core tasks of the welfare state (Midgley, 1997; Morel, Palier, Palme, 2012). A common definition of welfare is formulated as the sum of social rights recognised by citizens and the distribution of various resources necessary for people's well-being, health and the possibility to develop enriching life conditions and equality (Börjeson, 2011; Morel, Palier, Palme, 2012; Svärd, 2017). Social researchers studying social determinants found vulnerability and poverty to be very important factors in people's living conditions.

It is noted that social vulnerability is created at the complex intersection of economic, social, cultural, institutional and individual conditions, in relation to gender, class, ethnicity, sexuality, age and the ability of the body to function (Lalander, Svensson, 2014; Halleröd, 2006). Additionally, poverty is considered not just to be a lack of financial resources, but insufficient resources in several areas that also make families and their children visible to the social services (Lundström, Sallnäs, 2017; SCB, 2018). Although who is considered as poor varies over time and space, governments now routinely collect data on education, income, housing and other social conditions, and this approach results in the development of composite indicators of social welfare. A low economic level in Sweden refers to an economic position that is lower than 60 per cent of the median value in disposable income per consumption unit for all persons (SCB, 2018).

In this paper, I will take as a point of departure the assumption that a characteristic of welfare provision has an impact on people's life conditions (as in this study, 
young people aged 12 to 24 ), and consequently requires specific competence in the social professions. Against this background, I will point out some central aspects of socio-political characteristics considered to be important for young people's life conditions. The aim here is to highlight public statistics and structural factors regarding issues of youth education, training, employment and social capital matters, for they may be important factors in the education of the social professions to understand and meet the needs of vulnerable young populations. A particular focus is put on welfare distribution, especially financial vulnerability and poverty in today's young population in Sweden. The socio-economic dimension is fundamental to people's living conditions of all ages, but here the focus is more on the living situations of young people.

Sweden has a long tradition of national registers reporting socio-economic indicators and child welfare interventions associated with the public authorities, for instance Statistics of Sweden and the National Board of Health and Welfare (SCB, 2018; SOS, 2019). The empirical source for this study consists of a comprehensive reading of current literature, including public prints of several kinds, such as national investigations, public statistics and government reports. Furthermore, analyses of reviews of previous research on the subject and appropriate social studies relating to young people's living conditions were also surveyed.

The aim of this descriptive inquiry is to identify and analyse coexisting features of welfare provision regarding the young population. Some studies in youth and welfare provision concentrate on institutional provision, and, following that tradition, this paper will examine specific key areas affecting young people, with a focus on the general welfare landscape in Sweden, education and training, and young people as holders of rights regarding socio-economic vulnerability, employment and social care services.

This descriptive study is part of a larger research project carried out as a crossborder Erasmus + investigation and initiative to enrich social work education, with an education module directed at the future social professions to acquire the necessary tools for encountering and supporting their vulnerable young clients (European Commission, 2019). Five social work faculties and four countries, including Bialystok University in Poland, Malmö University in Sweden, Klaipeda University in Lithuania, Latvijas Kristiga Academia in Latvia, and Warszawa University in Poland, conduct the research, share perspectives and capacities, and collaborate in the development of evidence and collection of material for this project. 
Irena Dychawy Rosner

\section{The Swedish context of the welfare landscape}

Welfare, well-being and poverty

The 20th century may be called the century of the welfare state. European countries communicated a vision of welfare, evolution and attempts to adapt to the new socio-economic context of the post-industrial era. Notably to the OECD (1996), they have also continued social reforms. Central to this new thinking is an emphasis on developing policies that aim to position welfare rather than restore it. In the Swedish context, social policy transfers mainly as a distribution strategy for social reforms (Morel, Palier, Palme, 2012).

As is underlined by Morel, Palier and Palme (2012), different terms and labels, such as social development or social investment, have been used in modernising and positioning Swedish well-being and welfare. The social investment approach addresses governments to invest in the development of human capital, such as early childhood education and social care, and policies supporting risk groups, such as active labour market policies and regulations, but also welfare protection institutions, while increasing social protection and inclusion for groups that have traditionally been excluded.

Hans Svärd, a professor of social work, stated that the welfare state is one of the most important social innovations of the 20th century (Svärd, 2017). It has reduced poverty, improved children's living conditions, distributed resources over the life cycle, and provided protection in cases of illness, accidents, unemployment and childcare. In spite of the intensive reform work of recent years, questions have been raised about how the Swedish welfare state really is. Trying to alleviate the difficulties of life in terms of illness, ageing, disability and livelihood problems is probably the main task of the welfare system. According to Svärd (2017), the Nordic, and especially the Swedish, welfare model is considered to rest on four foundations:

(1) The first is based on a high degree of general and collective solutions most stated by public laws and less individually tested rights;

(2) Further, the Swedish welfare regime is strongly grounded on trust in the system of the public sector, and consequently holds relatively positive attitudes towards the payment of taxes;

(3) The social welfare contract is based on mutual obligation between the state and the individual. Correspondingly, there is great confidence and belief in a good state;

(4) Swedish society is very dominated by a spirit of compromise, which results in peace and relatively few strikes in the labour market. 
THE SWEDISH SOCIAL LANDSCAPE IN SOCIAL WORK PRACTICE WITH...

Table 1. A summary of perspectives in Swedish social policy thinking*

\begin{tabular}{|l|l|}
\hline Type of social policy aims & Notes on social policy thinking \\
\hline With respect to social goals & $\begin{array}{l}\text { Investment in prevention and human capital, in order to } \\
\text { achieve development, growth and prosperity } \\
\text { Promotion of equality of opportunity, gender equality }\end{array}$ \\
\hline With respect to education & $\begin{array}{l}\text { Allocation of human capital at all levels of education and } \\
\text { supported lifelong learning }\end{array}$ \\
\hline $\begin{array}{l}\text { Citizens' duties with respect } \\
\text { to the labour marker }\end{array}$ & $\begin{array}{l}\text { All citizens have a duty to work, but they may also have } \\
\text { the right to an adequate income } \\
\text { Citizens have rights with respect to income security e.g. } \\
\text { benefits when ill-health and age make employment im- } \\
\text { possible, or parental leave and flexible work time }\end{array}$ \\
\hline $\begin{array}{l}\text { With respect to publicly } \\
\text { funded services }\end{array}$ & $\begin{array}{l}\text { Publicly funded services for those without adequate } \\
\text { income or who need support }\end{array}$ \\
\hline
\end{tabular}

*Adapted from Jenson (2012)

Consequently, Swedish social policy addresses individual security, advocating social rights, guaranteeing income security, and reducing income inequality. An important element in contemporary social policy regimes is the assumption of citizens' rights and duties. A summary of perspectives of relationships in social policy thinking are presented in Table 1.

In recent years, the generous social policy in Sweden has raised discussions that it was responsible for poor motivation in searching for jobs, and the creation of dependency (Jenson, 2012). Further, the cost of wealth-creating structures increased expenditure, and social policies were portrayed as a cost rather than a stimulator of economic growth and social stability. These views and discourses raised questions about the role of the state (Rothstein, 2002) and the reallocation of social responsibilities toward other social actors. Public organisations have undergone major changes in their management, and New Public Management (NPM) affects administrative ideas and other initiatives drawing on efficiency-improving techniques from the private sector. These new ideas formed the social policy, from passive social security benefits to the stronger emphasis on activation in the implementation of social strategy (Morel, Palier, Palme, 2012), and impacted the social professions (Alvehus, Anderson, 2018). However, there are still tensions, contradictions and failures in combining social protection, social promotion and the productive effects of the rights of social citizenship (Swärd, 2017; OECD, 1996). 
Nowadays, there are different perceptions and interpretations about how the welfare state and the Swedish model are changing, and what they are facing. Belief in financial management, evidence and competition has grown strongly, and the rules for compensation in certain areas, such as payments for unemployment or health insurance, have decreased. Voluntary organisations have stepped into areas where the welfare system has left a vacuum, and operate in shelters for the homeless and other vulnerable people. Through increased globalisation, Europeanisation and greater social mobility, welfare and citizenship have changed their character. The presence of migrants in a society generally raises the multiculturalism issue. It is mainly refugee migration, and the need to take measures for integration, that create the main challenges in local and global society (Björgren Cuadra and Staff, 2012; Dychawy Rosner, 2016; Eriksson-Sjöö, 2012). Poverty has grown in several EU member states, and social exclusion has affected young people, such as undocumented people and young people migrating alone, and people living on the margins of the community (Migration Policy Index, 2015). Some problems of exclusion among young people today have strong elements of gender, class and ethnicity (Grander, 2018; Lalander, Svensson, 2014; Malmö Kommissionen, 2013; SCB, 2013).

Sweden is characterised by a high level of public trust, but that does not automatically mean a breakthrough in the form of confidence in the governance of the public sector. Serious youth problems and growing gaps in the population have shown deficiencies in security and safety, and in not being able to redistribute resources both horizontally across the life cycle and vertically between different groups. Contemporary social research highlights the growing social inequality and segregation in Swedish society. Inequality occurs on different levels. It can be about people sinking into homelessness, or growing up in conditions characterised by insecurity and poverty (Björkhagen Turesson, 2019), and young populations outside the labour market (SCB, 2013). There are shortcomings in the gaps between formal laws and guidelines on one hand and real conditions (SOU, 2011, p. 61). Social policy measures have increasingly been directed at the individualisation of social problems, which creates expectations that the individual should manage his or her own problems, and measures aimed at the equalisation of society's resources have been insecure (Svärd, 2017; Lorentzen et al, 2014).

\section{Education and training}

Giving every person a good start in life, safe conditions for growing up, and the conditions to manage school are the most important investments a society can make. Theoretical arguments for improving the connection of individuals to the 
labour market embody ideas about the acquisition of knowledge and skills. In fact, the most obvious method for attaining competence for a knowledge-intensive labour market is education and training (SI, 2019). The most advanced industrialised countries have implemented compulsory education laws, the length of which extended throughout the 20th century (OECD, 2018). Enrolment in most continental and Nordic welfare states rose to incorporate almost all school-age children in primary and secondary education. In a similar way, tertiary education has become more important over time, as a source for theoretical knowledge-driven economic growth strategy, poverty reduction, and training a qualified and acceptable labour force.

The greater focus of welfare policies on social citizenship and the emphasis on the importance of paid employment was a starting point for investment in human capital, with the idea that Sweden should be able to compete easily through the high quality of all levels of school (from preschool to higher education). The Swedish education system offers good opportunities for a free education. The school system is tax-financed, and regulated through the Education Act, which mandates ten years of school attendance for all children from the year they turn six (SI, 2019). Compulsory schooling in Sweden consists of four stages: förskoleklass (pre-school year), lågstadiet (years 1-3), mellanstadiet (years 4-6) and högstadiet (years 7-9). Children between the ages of six and 13 are also offered out-of-school care before and after school hours.

In 2017, around 90 per cent of upper secondary learners received a leaving qualification (SI, 2019). The National Agency for Special Needs Education and Schools provides children (Skolverket, 2019), young people and adults with disabilities with the same opportunities for development and education that everyone in society is entitled to. A completed upper secondary education is crucial for entering the labour market. However, far from all high school graduates have a degree. Young people themselves primarily indicate school fatigue as a reason why they did not complete their educational diploma. Of those who started at high school in 2011, one in three did not graduate after five years (Kossack, 2017).

According to Swedish national statistics, from the fourth year after upper secondary school, people who studied in higher vocational education directly after upper secondary school integrated into the labour market to the greatest extent. Three years after upper secondary school, 39 per cent of the men were integrated into the labour market, compared with 26 per cent of the women. Furthermore, a comparison of employed people's occupations seven years after upper secondary school shows that women had an occupation that required both basic and in-depth higher education qualifications to a greater extent than men (SCB, 2019). 
A Malmö commission report (Malmö Kommissionen, 2013) on determinants of health inequality from a lifetime perspective points to structural factors, such as income inequality and access to education, as the most important of these determinants. In Sweden, approximately three out of ten 20 -year-olds did not graduate from high school in 2016 (Kossack, 2017). This group are at greater risk, developing health problems in later life (OECD, 2018) and economic vulnerability (Bradley, Stephens, 2007), and across OECD countries, people without educational results are less likely to participate in the workforce.

Differences in health and living conditions arise from the conditions in which we are born, grow up, work and age. This is just over four years for women and six years for men of the remaining lifespan at the age of 30 among Malmö residents with pre-gymnasium and post-secondary education (Malmö Kommissionen, 2013). Swedish statistics show that in total, after upper secondary school, women continued their studies in municipal adult education, folk high school and higher education more than men, who largely studied in higher vocational education. For example, among women, 64 per cent enrolled in a higher education programme at some point after upper secondary school, compared with 48 per cent of men.

There also exists a gender disparity in educational choices in higher education. The most common women's choice is to study the social sciences, law, business and administration. The second most common field of study, and the field with the most men, was engineering, manufacturing and construction. This is followed by health and welfare, which was also the field with the most women. The older the pupils are, the more they feel stressed at school. Regarding the question whether children feel stressed due to the high demands put on them, for pupils in upper secondary school, 62 per cent of girls, and 19 per cent of boys, feel this stress (SCB, 2015). Other studies have confirmed a strong association between competing secondary education and low family socio-economic position (Winding, Andersen, 2015). At the same time, poor social relations were more strongly associated with not completing a secondary education.

In summary, the multifaceted aims of education systems reflecting social development facilitate building a capacity to access existing collections of global knowledge, and to adapt that knowledge to local use. Once attended by a handful of the elite, European universities now educate through a strong partnership system and a quality agenda (EACEA, 2018; OECD, 2007). The great importance of the internationalisation of higher education to investing in cross-cultural skills, and the development of professionalisation, creating synergy and reducing barriers between these dimensions, is also a central theme in research and social work education (Acienè, Maciulskytè, 2016; Dychawy Rosner,Christiansen, 2016; Eriksson Sjö, 2012; OECD, 2018). 


\section{Young people as holders of rights}

The principle of the best interests of the child and youth is emphasised as basic protection in the Convention on the Rights of the Child. Although the Convention guarantees certain rights (UNICEF, 1989), poverty and marginalising social divisions can jeopardise these attempts.

Socio-economic vulnerability

Among people who work, there are very few who risk income poverty. In Sweden, this level has remained unchanged at 4 to 5 per cent since the early 1990s. Contract-regulated minimum salaries and a regulated labour market means that Sweden does not have a poor working population. On the other hand, income poverty has increased dramatically among those of the young population who are outside work or studies. According to official statistics, in 2016, 18 per cent of children and young people in Sweden (aged 0 to 19) lived in households with low financial standards, besides single women with children. Until the turn of the millennium, income poverty in this group was around 6 to 8 per cent. This has subsequently quadrupled to 28 per cent, and now almost every fourth person without a job or studying is income poverty-stricken (SCB, 2018).

At the same time that economic standards have generally increased, with increasing disposable income, the proportion of low economic standards has increased. The vast majority of households are economically better off; nonetheless, close to 1.4 million of the total population live in households with a low economic level (SCB, 2018). Differences in income likewise mean that foreign-born people have a lower financial level than people born in Sweden do.

Employment

Among total employed people, 78 per cent work full-time, 67 per cent of women and 87 per cent of men. For people with disabilities and reduced work capacity, 60 per cent work full-time, 47 per cent of women, and 75 per cent of men. Employment was the most common activity after upper secondary school, both one year and three years after completing education. This was regardless of whether young people finished upper secondary school with or without a leaving certificate (SCB, 2019). Young people outside the labour force perhaps have health and/or social or other problems. A cohort study in Norway identified three main barriers to education or employment: motivation, the sense of a lack of achievement, and unrealistic expectations of working life (Osborg Ose, Jensen, 2017). Further, an internet-based survey among 586 people aged 18 to 29 revealed other barriers, such as health problems $(60 \%)$, poor education $(55 \%)$, a lack of work experience $(41 \%)$, low self-esteem (36\%), and feeling depressed (35\%) (ibid). The nature of the problems of poor health and social inequality were correspondingly reported by other 
researchers in Sweden (Lorentzen et al., 2014; Sellström, Bremberg, O'Campo, 2010; Åhs, Westerling, 2006).

The Thematic Report of Labour Force survey in a European comparison (SCB, 2013) for the first quarter of 2013 describes the situation of the young people's labour market from an international perspective. Comparisons were made mainly for the central measures of employment, unemployment and labour force figures. The division into younger and older youth, as well as students and non-students, further qualifies these measures. The report highlights that Sweden has a high youth unemployment rate internationally. In 2011, the unemployment rate of those aged 15 to 24 was 22.8 per cent. The Netherlands had the lowest youth unemployment rate in the countries surveyed, with 7.7 per cent. The highest youth unemployment rate was 46.4 per cent in Spain. Unemployment was higher in the 15 to 19 age group than in 20 to 24 years in all the countries surveyed. Differences between the countries were most pronounced in the younger age category, while the unemployment rates for the countries converged in the older age groups. The differences between countries were greater among students than among non-students (ibid). The international measure NEET (not in employment, education or training) is another indicator of the young people's labour market situation. It shows the proportion of young people who neither work, study nor attend a labour market policy programme. Among Swedish youth, it was 7.5 per cent unemployment proportions in 2011. These ratios grow, and in 2018, youth unemployment included at most 39.4 per cent for the ages 15 to 19, and 15.4 per cent between 20 and 24. Young people's incomes generally vary more over the years than for the older population. Despite the fact that young people's income as a whole is increasing with increasing age, there are some people in the ages 20 to 29 (270,000 in 2010) corresponding to 10 per cent of the population with the lowest net income. Of this group were 40,000 people, or 15 per cent, with a permanently low income. Almost 5 per cent of these are classified as students, while more than 40 are not studying or do not participate in education. Of those who had low incomes in 2000-2005, 29.3 per cent had low incomes in 2015, while 4.3 per cent belonged to the high income group (Lindberg, 2017).

There is a diversity of beliefs about why unemployment persists, and what should be done to address it. For example, the economy arguably influences and places an important role on how many students participate in various forms of education or are encouraged to participate in lifelong learning. The quality of education and participation in the labour market also depend on how much economic resources are devoted to each student, and the possibilities for access to the employment market. 
THE SWEDISH SOCIAL LANDSCAPE IN SOCIAL WORK PRACTICE WITH...

Table 2. A summary of the young population of Sweden outside the labour market *

\begin{tabular}{|l|l|}
\hline Unemployment status & Numbers in per cent \\
\hline Total unemployment & 6 \\
\hline Youth unemployment 15-24 years old & 16.8 \\
\hline Men & 18 \\
\hline Women & 15.5 \\
\hline Total unemployment of people with disabilities & 11 \\
\hline Men & 75 \\
\hline Women & 67 \\
\hline Need for aid & 80 \\
\hline & \\
\hline
\end{tabular}

*Source: SCB. (2019-01-24) Ungdomsarbetslöshet i Sverige.

It is sometimes mentioned that Sweden has higher youth unemployment than other EU countries. There are several important reasons for this. One of them is that Sweden has no learning practice system, as many other EU countries have. Paid apprentices do not count as unemployed. Another reason is that young people in Sweden do not receive student support in the summer, and therefore seek jobs more than in other EU countries.

In Sweden, therefore, a greater proportion of young people are defined as being unemployed before and at the beginning of summer than in other EU countries, as they need to apply for jobs when they do not receive support. Poor access to summer jobs raises the unemployment rate for young people in Sweden.

\section{Social care services}

Backe-Hansen et al. (2013), in an overview of the current out-of-home situation in Norway and Sweden, found the out-of-home placement of children and young people to be an integrated part of the welfare state. Even if socio-economically vulnerable families are the subject of efforts in social work and social care, trends show that more children and young people have been taken from the home, even before unaccompanied children and young people appeared (Lundström, Sallnäs, 2017). There are some interventions that can, in principle, be managed by general systems; but when these show deficiencies, there is a need for special interventions for young people as a 'risk group' for being placed in institutional family care (SOU, 2009, p. 68; 2011, p. 6; 2011, p. 61). As an alternative, when the parents, or parent, develop drug, alcohol or mental problems, separation is found to be necessary, for example, to place the children and young people in a foster family. Although widespread importance is put on the relationship with the family of origin, and on working towards a reunion (Mitchel et al., 2010), practitioners often 
Irena Dychawy Rosner

find it hard to achieve regular contact that is acceptable to all parts involved (Lindahl and Bruhn, 2017).

According to the Social Board (SOS, 2019), in 2018, 38,800 children and young people in Sweden received social services care at some point during the year, according to the Social Services Act (SoL), or interventions according to the Act on Special Provisions on the Care of Young People (LVU). The most common type of placement was family homes. Of the children placed, just under 30 per cent were unaccompanied children and young people. The most common type of placement for unaccompanied children and young people was a care home or housing (HVB), followed by family homes (SOS, 2019). About 70 per cent of all children and young people with full-day care in 2018 were between 15 and 20 years old.

For the group of unaccompanied children and young people, over 90 per cent were 15 to 20 years old. Children and young people with full-day care are usually placed in family homes. Of the children and young people who once received a social care contribution in 2018, 23,100 (48\%) were placed in family homes. Just over 60 per cent of those placed in family homes were boys, and 40 per cent were girls.

The second most common form of social care (30\%) was home care or accommodation (HVB). About 77 per cent of those placed on HVB were boys, and 23 per cent were girls. Boys are in the majority of all social care types. The largest percentage difference regarding type of placement and gender can be found in the placement type of support housing, where the proportion of boys was 86 per cent. Among unaccompanied children, HVB was the most common type of placement until 2018. In 2018, 37 per cent were once placed on HVB. Family homes are the second most common form of placement for unaccompanied children: 32 per cent were placed in family homes some time in 2018. Most (77\%) 24-hour intervention given to children and young people in 2018 was decided in accordance with special institutional care (LVU care), or an alternative decision immediate treatment according to $\S 6 \mathrm{LVU}$ (SOS, 2019).

Andersson (2008) completed a longitudinal research after disadvantaged children had left home. Following successive strategies during childhood and early adulthood, the results showed instability in placements as a risk factor, especially for teenagers. Furthermore, inclusive attitudes from the foster family were shown to promote continuity and the growth of a sense of security. Vinnerljung and Sallnäs (2008) conducted a long-term analysis of 700 young Swedish people taken out of home care during their teens. They found in this cohort study very high rates of premature death, prison sentences, serious involvement in crime, mental health problems, and teenage parenthood. Young people who were older in placement 
THE SWEDISH SOCIAL LANDSCAPE IN SOCIAL WORK PRACTICE WITH...

tended to do better than others did. It seems that having a history of residential care increased the poor prognosis of positive outcomes in later life.

\section{Discussion}

When we consider the situation of socio-economic standards in Sweden's welfare state, it is obvious that it is in many ways better now than before (Heggemann, 2018). There is potential in a young and increasingly well-educated population, and an expansive development of jobs and education. This also requires a housing market that facilitates establishment and resettlement patterns throughout the life cycle (Salonen, Grander, Rasmusson, 2019). General life improvements apply to the material as well the living conditions, and the way society relates to young people as part of society.

Nevertheless, surprisingly, maping contemporary issues in the social welfare landscape regarding the youth population in Sweden showed several challenges and important obstacles to social work students and other future social professions. A great need was shown for society's recognition of inclusiveness and the existing insecurity of the young population, and how it should be expressed in actual social policy actions, regarding housing, employment, future possibilities, and equality status. The existing labour market policy is changing, depending on the state of the economy. However, the results of this study show that the limited generosity of recent years, i.e., unemployment insurance or restrictions relating to the payment of sickness benefits, ensure that recipients feel some financial pressure and difficulties re-entering the labour market (SCB, 2018). Early research found evidence that restrictive polices increase employment levels (Bradley, Stephens, 2007), but the picture retrieved from the research literature shows increasing vulnerability (Björgren Cuadra and Staff, 2012; Enel loch Vogel, 2018; Lorenzen, et al., 2014), poverty (SCB, 2018), and a need for help from social services (Andersson, 2009; Vinnerljung, Sallnäs, 2008; SOS, 2019).

Contemporary social research illuminates how the organisation of institutional care sometimes makes it impossible to deliver individually tailored care (Enell, Vogell, 2018; SOU, 2011). The rules are adapted to group-level assessments related to safety, and are more rarely based on young people's treatment-related needs (Björkhagen Troesson, 2019; Salonen, Grander, 2019). Enell and Vogel (2018) describe the results of their research in which they found situations where treatment efforts never come to implementation, were found to be delayed, terminated prematurely, or were forced to start again due to organisational and personnel administrative reasons. The problems of young people placed in special youth homes are both heterogeneous and complex. These problems may be based on numerous 
combinations of crime, abuse, psychiatric diagnoses, school problems and family problems, and exhibit frequent exposure to violence and abuse (Åhs, Westerling, 2006; Enell, Vogel, 2018; Vinnerljung, Sallnäs, 2008). Although the welfare model provides general benefits to citizens, the model does not focus especially on children and young people (Bake-Hansen et al., 2013). Criticism from researchers has also been about young people with severe mental illness or neuropsychiatric disabilities placed in special youth homes, although the institutions often lack staff with the skills to deal with these problems (Enell, Vogel, 2018; SOU, 2011). The fact that institutional social care plays such a central role in Swedish youth care should be regarded as a failure of social work practice with young people. Political voices in the media are beginning to highlight the importance of more long-term preventive work (Hoti, Grönholm, 2019). Locking up young people in institutions should be done when everything else is considered to have failed. Social services should largely be where children and young people are, i.e. in schools to support well-functioning schooling. Dychawy Rosner (2007), conducting citizen dialogues such as Dialogue Forum with members of all social classes in a medium-sized municipality in southern Sweden, found deficiencies in the school environment, and young people's need for more comprehensive access to the school nurse, social worker and foremost, support in connection with interplay between and within various youth groups, besides prevention of bullying processes. There was also a need for better-structured open social care for addicts, and more interventions that are socially relevant and aimed at abusers and young people returning from a forced placement or a completed prison sentence.

In proposing new ideas for promoting economic growth in a socially protective way, there is a need for more government interventions in cohesive social investment. These concerns regard promoting employment, participation in diverse public arenas, and the development of quality in high-school education, and with improving the cognitive and social skills of young people. Gender and ethnic disparities were evident in each principal field, for example, in educational choices, in challenging behaviour, and entrance to the labour market (Kossack, 2017; SCB, 2013; 2015).

The Swedish government is using social policy and legislative instruments to structure the welfare context and social division context within which the social work professions have to operate. Alongside this concern, there is another one, which draws on professional understandings, the competence of the social professions, and knowledge that promotes the interests of society's most marginalised groups. Students of social work and other social professions are expected to understand the structures of welfare provision, and to be able to examine how these structures are directed towards meeting needs. Future social professions, being 
able to operate effectively in existing socio-economic, socio-political and social reality milieus, need to cope with clients' world as they find it, adopting a more holistic and preventive approach to social interventions (Adams, Dominelli, Payne, 1998; Björkhagen Troesson, 2019; Dychawy Rosner, 2017).

Professional areas of work with the vulnerable young population, assignments and knowledge are what Bauman calls an explosive field. He sees the growing social inequality in the world, and the increasing extent of human suffering of those assigned the status of 'collateral', expressing consequences that are unplanned, but nevertheless a damaging silent dimension of social inequality (Bauman, 2011). In order to change the social services from being a distribution policy to preventive measures, family social professional reception and care centres should expand for those who need extra support in the parental role, which can create safer families and childhood. Members of the social professions require a critical socio-political rethink as to who should be included in the distribution of welfare (Adams, Dominelli, Payne, 1998).

To sum up, an analysis of the findings related to socio-structural development trends in social work with young people in Sweden have discerned differences between institutional and administrative views versus ones that take into account the growth of individual strengths, his/her supporting environmental factors, and holistic and preventive approaches in the implementation of work. There is a need for considerations based on preventive and anthropological approaches that boost personal protective factors in the individual's immediate world, and then supportive environmental factors, for instance, positive social networks need to extend the main social work practice with youth. In order to be enable to change perspectives, it a process-related approach must always be used, which can be both reproduced and questioned. For example, the problems that arise in the use of categorisation, such as unemployed, youth with troublesome behaviour, or immigrant, create collateral damage (Bauman, 2011) through attitudes that define the individual, and in practice create barriers to opportunities in the individual's everyday life. This means that the young person's life problems should be entered into various areas of professional knowledge and existing specific socio-political tools. Since the social professions work on clients' problems with numerous authorities, and their implementation can refer to various tools, a holistic assessment can be difficult, and therefore also the possibilities of allocating responsibility.

\section{Conclusion}

A synthesis of the literature in this study has identified several risk factors of significance to both individual indicators and a societal perspective in the young 
population. The introduction of government welfare programmes will reflect established notions of equality, but the current social programmes seem to reinforce existing patterns of inequality and errors in access to benefit levels, and in many cases show contradictory functions. Across Europe and other advanced economies, there has been an alarming rise in the levels of young people (aged between 16 and 24) who are detached from both the labour market and the education and training system.

To catch a young individual's difficulties in everyday life, and formulate appropriate support, the social professions should move from a normative categorising policy to a more anthropological-based knowledge social policy, and investment in human resources. The starting point for social work should be the person's world, their experience, and how everyday life expresses diverse forms of vulnerability, or how social problems can be stopped, helped, or made possible. Procedural considerations are also crucial in the realisation of social work practice among young populations. This is in contrast to the traditional understanding of mere goal achievement, rather than on mechanisms whereby these can be reached.

A fuller understanding of young people's welfare composition requires an examination of it from multiple perspectives. Questions are raised about the nature of the welfare protection system and effective service delivery. Wealth is gradually increasing in society; how is it possible that poverty issues and social vulnerability with respect to the young population are still topical? And in what way should professional educational programmes prepare future social workers to maintain a reflected position between individual and social factors? These questions may be important matters for future research into young disadvantaged people's living conditions. Finally, the results of this study call for comparative research examining the benefits and pitfalls of the Swedish social landscape in social work practice with young populations in other countries (Poland, Lithuania and Latvia) participating in this EU project.

\section{Acknowledgement}

This work is part of a project which is financially supported by the European Commission, Erasmus + KA2 Programme.

\section{References}

Abbott, A. D. (1988). The system of professions. Chicago: University of Chicago Press.

Aciené, E., \& Maciulskyté, S. (2016). On the discourse of social work professionalization. The innovative content of caritative social work. Latvian Christian Academy Proceedings, Vol. (4), p. 80-96.

Adams, R., Dominelli, L., \& Payne, M. (1998). Social Work: Themes, issues and critical debates. NY: Palgrave. 


\section{THE SWEDISH SOCIAL LANDSCAPE IN SOCIAL WORK PRACTICE WITH...}

Andersson, G. (2009). Foster children: a longitudinal study of placement and family relationships. International Journal of Social Welfare, Vol. 18, p. 13-26.

Alvehus, J., \& Andersson, T. (2018). New professional landscape: Entangled Institutional Logics in two Swedish welfare professions. Nordic Journal of Working Life Studies, Vol. 8 (3), p. 91109. DOI at https://tidskrift.dl/ njwls/index.

Backe-Hansen, E., Höjer, I., Sjöblom, Y., \& Strö, J. (2013). Out of home care in Norway and Sweden - similar and different. Psychosocial Intervention, Vol. 22, p. 193-202.

Bauman, Z. (2011). Collateral damage: social inequalities in a global age. Cambridge: Malden Polity Press.

Björgren Cuadra, C., \& Staff, A. (2012). Public social services encounters with irregular migrants in Sweden. Amid values of social work and control of migration. European Journal of Social Work, December, p. 1-16.

Björkhagen Turesson, A. (ed.) (2019). Hemlösa barns vardagsliv i Malmö: Utifrån ett barnperspektiv [Homeless children's everyday life in Malmö: from a children's perspective]. FOU rapport, Vol. 4. Malmö: Malmö University

Bradley, D., \& Stephens, J. D. (2007). Employment performance in OECD countries: a test of ne-liberal and institutionalist hypotheses'. Comparative Political Studies, Vol. 40 (12), p. 1-25.

Brante, T. (2013). The professional landscape: The historical development of professions in Sweden. Professions \& Professionalism, Vol. 3(2), p. 1-18.

Börjeson, B. (2011). Att förstå social arbete [To understand social work]. Stockholm: Liber.

Dychawy Rosner, I. (2016). Challenges of migration for the social pedagogy in Swedish context. Papers of Social Pedagogy, Vol. 1(4), p. 6-16. https://pedagogikaspoleczna.uw.edu.pl/resources/html/cms/MAINPAGE

Dychawy Rosner, I., \& Christiansen, J. (2016). Globalisation brought into the classroom - Reflections from the local context in social work and nursing education. Tiltai: Bridges in Social Sciences, Vol. 74(2), p. $21-32$. http://journals.ku.lt/index.php/tiltai/article/view/1364

Dychawy Rosner, I. (2007). Samtal om närsjukvården I Bromölla [Talks about local health care in Bromölla municipality]. Kristianstad: Högskolan Kristianstad. Forskningsplattformen för utveckling av Närsjukvård, FOU: Collaborative and Integrated approaches to health, Vol. 2.

Dychawy Rosner, I. (2017). Preventive interventions in socio-pedagogical social work. Papers of Social Pedagogy, Vol. 1(6), p. 24-36.

EACEA. (2018). European Commission Erasmus programme. www.eurodesk.eu

Enell A., \& Vogel, L. (2018). Behov av förändring vid särskilda ungdomshem. [Needs for change in special youth homes]. In M. Dahlstedt, P. Lalander. Manifest för ett socialt arbete, p. 173-184. Lund: Studentlitteratur.

European Commission. (2019). EACEA, Erasmus + KA2. Cooperation for innovation and the exchange of good practices. Bryssel: https://eacea.ec.europa.eu/erasmus-plus/actions/key-action-2-cooperation-forinnovation-and-exchange-good-practices en

Eriksson Sjöö, T. (2012). Utmaningar och bemötande i flyktingmottagandet [Challenges and response in the refugee reception]. FOU rapport, Vol. 3. Malmö: Malmö högskola.

Grander, M. (2018). Of the beaten track? Selectivity, discretion and path shaping in Swedish public housing. Housing, Theory and Society, Vol. 1-16. https://doi.org/10.1080/14036096.2018.1513065

Halleröd, B. (2006). Sor graper: Relative depriviation, adaptive preferences and measurement of poverty. Journal of Social Policy, Vol. 35(3), p. 371-390.

Heggemann, H. (2018). Fler eller färre fattiga? [More or less poor?]. Välfärd, Vol. 3, p. 22-23.

Hoti, S., \& Grönholm, J. (2019). Ställ om socialtjänsten till en organisation med tyngdpunkt på förebyggande arbete [Transfer the social service to an organisation with a focus on preventive work]. Sydsvenskan, A4. Opinion.

Jenson, J (2012). Redesigning citizenship regimes after neoliberalism: moving towards social investment. In: N. Morel, B. Palier, J. Palme. Towards a social investment welfare state? Ideas, policies and challenges, p. 61-87. Bristol: The Policy Press.

Kossack, P. (2017). 3 av 10 tar inte examen från gymnasieskolan [3 out of 10 do not graduate from high school]. SCB Välfärd, Vol. 3, p. 21-23.

Lalander, P., \& Svensson, B. (2014). Perspektiv på social utsatthet. Lund: Studentlitteratur.

Lindberg, J. (2017). Ökning av andelen unga med varaktig låg inkomst [Increase of the proportion of young people with long-term low income]. SCB Välfärd, Vol. 3, p. 13-17.

Lindahl, R., \& Bruhn, A. (2017). Foster children's experiences and expectations concerning the child-welfare officer role: Prerequisites and obstacles for close and trustful relationships. Child \& Family Social Work, Vol. 22 (4), p. 1415-1422. 


\section{Irena Dychawy Rosner}

Lorentzen, T., Angelin, A., Dahl, E., Kauppinen, T., Moisio, P., \& Salonen, T. (2014). Unemployment and economic security for young adults in Finland, Norway and Sweden. From unemployment protection to poverty relief. International Journal of Social Welfare, Vol. 23(1), Vol. 41-51. http///dx.doi.org710.1111/ ljsw. 12006.

Lundström, T., \& Sallnäs, M. (2017). Den sociala barnavården [The social childcare]. H. Svärd (ed.). Den kantstötta [The edge hurt welfare], p. 223-248. Lund: Studentlitteratur.

Malmö Kommissionen. (2013). Malmös väg mot en hållbar framtid. Hälsa, välfärd och rättvisa [Malmö’s road to a sustainable future]. Malmö: Kommisionen för ett hållbart Malmö.

Midgley, J. (1997). Social welfare in global context. London: Sage Publications.

Migration Policy Index. (2015). How countries are promoting the integration of their immigrants. Retrieved from http://www.mipex.eu

Mitchel, M. B., Kuczynski, L., Tubbs, C. Y., \& Ross, Ch. (2010). We care about care: advice by children in care, foster parents and child welfare workers about the transition into foster care. Child and Family Social Care, Vol. 15, p. 176-185.

Morel, N., Palier, B., \& Palme, J. (2012). Towards a social investment welfare state? Ideas, policies and challenges. Bristol: The Policy Press, p. 1-19.

Rothstein, B. (2002). Vad bör staten göra? Om välfärdsstatens moraliska och politiska logik [What should the state do? About welfares, moral and political logic]. Stockholm: SNS Förlag.

OECD. (1996). Beyond 2000: The New Social Policy Agenda. Paris: OECD

OECD. (2018). Education at glance 2014. Paris: OECD. OECD Indicators. Retrieved 2019-12-08 from http:// www.cnedu.pt/content/noticias/internacional/Education_at_a_glance_2018.pdf

Osborg Ose, S., \& Jensen, C. (2017). Youth outside the labour force - Perceived barriers by service providers and service users: A mix method approach. Children and Youth Services Review, Vol. 81, p. 148-156.

Salonen, T., Grander, M., \& Roodro, T. (2019). Segregation och segmentering [Segregation and segmentation]. Malmö: Kansliet för hållbar utveckling.

SCB. (2018). Fattiga eller färre fattiga? https://www.scb.se/hitta-statistik/artiklar/2018/fler-eller-farre-fattiga/.

SCB. (2015). More girls than boys feel stressed in schools. Living conditions of children 2013-2914. Stockholm: Statistical news from Statistics Sweden. https://www.scb.se/.

SCB. (2013). Labour force survey: $1^{\text {st }}$ quarter 2013 - Theme Youth unemployment. Stockholm: SCB.

Skolverket (2019). Grundsärskolan. Retrived 2019-12-29 from https://sweden.se/society/education-in-sweden/

SI. (2019). Education in Sweden. Stockholm: Swedish Institute. https://sweden.se/society/education-in-sweden/

SOU (2011). Vanvård i social barnavård. [Uncare in social child care] Stockholm: Statens Offentliga Utredningar. Slutrapport, SOU 2011:61.

SOU. (2009). Lag om stöd och skydd för barn och unga. [Low about support and protection for children and young people] Stockholm: Statens Offentliga Utredningar. Slutrapport, SOU, Vol. 68.

SOS (2019). Statistik om socialtjänstinsatser till barn och unga 2018 [Statistics about social child and youth care]. Stockholm: Socialstyrelsen.

Swärd, H. (ed.) (2017). Den kantstötta välfärden [The edging welfare]. Lund: Studentlitteratur.

Sällström, E., Bremberg, \& O'Campo (2010). Yearly incidence of mental disorders in economically inactive young adults. European Journal of Public Health, Vol. 21 (6), p. 812-814.

UNICEF. (1989). Convention on the rights of the child. NY: UN Centre for Human Rights.

Winding, T. N., \& Andersen, H. (2015). Socioeconomic differences in school dropout among young adults: the role of social relations. BMC Public Health, Vol. 15, p. 1054. DOI 10.1186/s12889-015-2391-0.

Vinnerljung, B., \& Sallnäs, M. (2008). Into adulthood; a follow-up study of 718 young people who were placed in out-of-home care during their teens. Child \& Family Social Work, Vol. 13, p. 144-155. DOI:10.1111/j.13652206-2007.x

Åhs, A. M. H., \& Westerling, R. (2006). Mortality in relation to employment status during different levels of unemployment. Scandinavian Journal of Public Health, Vol. 34, p. 159-167. 
Irena Dychawy Rosner is an associate professor and doctor of medical sciences in the Department of Social Work at Malmö University.

Research interests: the development of local health and social care, risk groups in the welfare state, internationalisation at home $(\mathrm{IaH})$.

Address: Båtsmansgränd 25, 21833 Bunkeflostrand, Sweden

Phone: +46 406657520 .

E-mail: irena.dychawy.rosner@mah.se

Irena Dychawy Rosner - docentè, daktarè (medicinos mokslai), Malmès universiteto (Švedija) Socialinio darbo katedra, Jogailos universiteto (Lenkija) Sveikatos ir socialinès rūpybos katedros profesorè.

Moksliniai interesai: vietinès sveikatos priežiūra ir socialinè globa, rizikos grupès gerovès valstybėse, studijų internacionalizacija namuose.

Adresas: Båtsmansgränd 25, 21833 Bunkeflostrand, Švedija.

Tel. +46406657520.

El. paštas: irena.dychawy.rosner@mau.se 